BIOFARM

Jurnal Ilmiah Pertanian

ISSN Print: 0216-5430; ISSN Online: 2301-6442

Vol. 14, No. 1, April 2018

\title{
Abu Pelepah Aren (Arenga pinnata Merr.) sebagai Bahan Kosmetika Perawatan Kulit Wajah Kaya Antioksidan
}

\author{
Palm Fronds (Arena pinnata Merr.) as an Ingredient in Cosmetics that Treat \\ Antioxidants
}

Farida Oktavia dan Jerry Wungkana
Balai Penelitian Tanaman Palma
Jalan Raya Mapanget PO BOX 1004 Manado 95001
Telepon (0431) 812430, Fax (0431812017
Korespondensi Penulis: faridaoktavia26@gmail.com

\begin{abstract}
ABSTRAK
Kesadaran masyarakat untuk menerapkan hidup sehat dengan cara back to nature juga terkait dengan pemilihan produk kosmetika yang digunakan sehari-hari. Abu pelepah aren potensial untuk dimanfaatkan sebagai bahan kosmetika dengan kandungan antioksidan alami. Antioksidan alami bermanfaat untuk mengurangi jumlah radikal bebas yang dapat memicu timbulnya berbagai penyakit degeneratif. Bagian pelepah aren yang diolah menjadi abu merupakan pelepah aren ke-3 hingga ke-6. Pada abu pelepah aren mengandung logam mineral seperti magnesium, zink, dan aluminium yang berperan sebagai penghambat aktivitas tirosinase sehingga dapat digunakan sebagai alternatif bahan pemutih wajah. Kandungan metabolit sekunder pada abu pelepah aren berupa flavonoid, polifenol, tanin, saponin, kuinon, alkaloid, monoterpen dan seskuiterpen berpotensi sebagai anti bakteri Propionibacterium acnes dan Staphylococcus aureus yang menjadi pemicu timbulnya jerawat. Kandungan tanin merupakan golongan senyawa polifenol dan dapat berperan sebagai antioksidan alami sehingga aman digunakan dalam jangka panjang dan rendah efek samping.
\end{abstract}

Kata kunci: aren, pencerah wajah, metabolit sekunder, antioksidan, masker alam, abu pelepah

\begin{abstract}
Public awareness to implement healthy life by way of back to nature is also related to the choice of cosmetics products that are used daily. Palm fronds are potential to be used as cosmetic ingredients with natural antioxidant content. Natural antioxidants are beneficial for reducing the number of free radicals that can trigger various degenerative diseases. Palm fronds which are processed into ash are the third to sixth palm fronds. In palm fronds ash contains metal minerals such as magnesium, zinc, and aluminum which act as inhibitors of tyrosine activity so that it can be used as an alternative to facial whitening ingredients. The content of secondary metabolites in palm fronds in the form of flavonoids, polyphenols, tannins, saponin, quinine, alkaloids, monoterpenes and sesquiterpenes have the potential to be anti-bacterial Propionibacterium acnes and Staphylococcus aureus which trigger acne. The content of tannin is a class of polyphenol compounds and can act as a natural antioxidant so it is safe to use in the long term and low side effects.
\end{abstract}

Key Words: palm, facial lightening, secondary metabolites, antioxidants, natural mask, fronds ash

\section{PENDAHULUAN}

Istilah kosmetika berasal dari bahasa Yunani, yaitu kosmetikos yang berarti keahlian dalam menghias. Definisi kosmetika menurut Peraturan Menteri Kesehatan RI No. 140 Tahun 1991 adalah sediaan atau paduan bahan yang siap untuk digunakan pada bagian luar badan (epidermis, rambut, kuku, bibir dan organ kelamin bagian luar), gigi dan rongga mulut, untuk membersihkan, menambah daya tarik, mengubah penampakan, melindungi supaya tetap dalam keadaan baik, memperbaiki bau badan, tetapi tidak dimaksudkan untuk mengobati atau menyembuhkan suatu penyakit.

Kosmetika dari bahan alami telah digunakan oleh para bangsawan Mesir sejak tahun 3000 SM dan menyebar keseluruh bagian penjuru dunia melalui jalur komunikasi dalam kegiatan perdagangan penyebaran agama, budaya, politik dan militer. Sedangkan di Indonesia, sejarah kosmetologi telah dimulai jauh sebelum zaman penjajahan Belanda. Saat ini kosmetika telah menjadi kebutuhan 
primer bagi hampir seluruh wanita dan sebagian kecil pria sebagai salah satu penunjang estetika.

Organ tubuh yang terletak paling luar dan membatasi dari lingkungan hidup manusia adalah kulit. Bagian kulit sangat esensial dan vital serta menjadi cermin kesehatan dan kehidupan setiap individu pemiliknya. Karakteristik kulit sangat kompleks, elastis dan sensitif, sehingga membutuhkan perlakuan khusus agar terjaga dan tidak tampak menua sebelum masanya. Keinginan individu untuk tampil cantik dan lebih percaya diri merupakan faktor utama yang mendorong penggunaan kosmetika terutama pemutih wajah. Tujuan penggunaannya agar dapat menghilangkan atau mengurangi hiperpigmentasi pada kulit.

Kekhawatiran muncul bagi para pengguna kosmetika, karena semakin marak produk kosmetika yang menggunakan bahanbahan berbahaya seperti merkuri, hidrokinon dan pewarna yang dilarang. Efek penggunaan produk pemutih wajah berbahan merkuri pada awalnya membuat kulit wajah tampak bersih dan sehat, namun setelah pengguaan jangka panjang kulit akan menghitam, timbul jerawat parah, pemicu kanker kulit, kanker payudara, kanker leher rahim, kanker paru-paru, dan jenis kanker lainnya. Reaksi efek samping kosmetika cukup parah akibat penambahan bahan aditif untuk meningkatkan efek pemutih, penggunaan jangka panjang pada area yang luas pada tubuh, ketidaksesuaian jenis bahan dan kulit serta iklim panas yang terjadi di Indonesia memicu daya absorbsi kulit. Hal ini terjadi karena kulit memiliki jaringan celah anatomis yang dapat menjadi jalan masuk zat-zat yang melekat di atasnya dan berdampak toksik.

Kosmetik yang berkualitas tidak boleh mempengaruhi fisiologi tubuh dan hanya bekerja pada lapisan epidermis kulit, bahan kosmetik yang diolah memenuhi standart dan persyaratan mutu serta memperoleh ijin edar dari BPOM. Hidup sehat dengan cara back to nature atau menggunakan kosmetika dari bahan alam menjadi alternatif dalam usaha perawatan kulit wajah yang sehat dan tampak berseri alami. Pemanfaatan tumbuhan oleh masyarakat lokal sebagai bahan untuk kebutuhan sehari-hari baik obat herbal, kesenian, kosmetik, dan lainnya disebut etnobotani. Pengetahuan masyarakat diperoleh dan diwariskan dari generasi ke generasi melalui tradisi lisan sehingga terbatas di lingkungan suku dan keluarga tertentu.
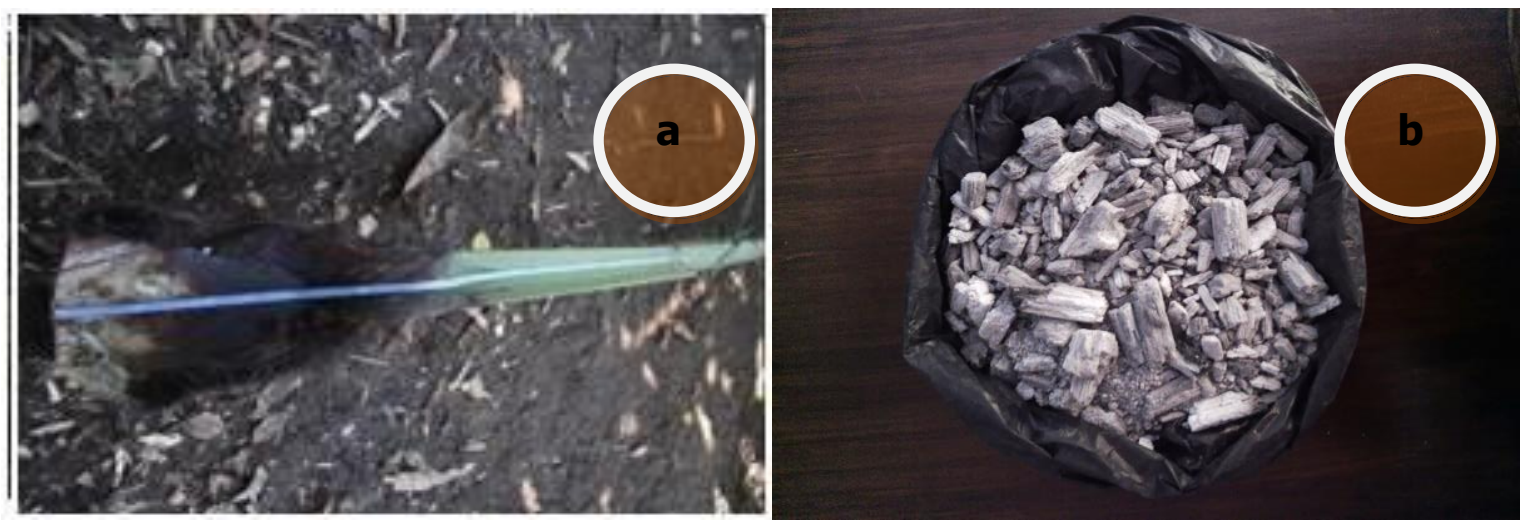

Sumber: Balitka.litbang.pertanian.go.id (a); bedak-aren.blogspot.co.id (b);

Gambar 1. Pelepah aren yang baru diambil dari pohonnya (a) dan abu pelepah Aren/sarerang kawung (b).

Tanaman aren mudah ditemukan hampir diseluruh wilayah Indonesia (Iswanto, 2009) karena tanaman aren merupakan salah satu jenis pohon suku Areceae yang tumbuh subur di kawasan hutan tropik. Masyarakat pada umumnya memanfaatkan tanaman aren hanya sebatas disadap niranya untuk diolah menjadi gula dan tuak. Senyawa-senyawa fitokimia pada umumnya mempunyai ciri khas dan sangat berperan dalam perkembangan ilmu medis. Rimpang famili Zingiberaceae banyak mengandung zat metabolit sekunder 
seperti alkaloid, flavonoid, saponin dan minyak atsiri yang sangat banyak dimanfaatkan di bidang kosmetika dan pengobatan (Wiwin 2011).

Bagian tanaman aren yang biasa digunakan sebagai bahan obat adalah akar dan nira. Akar aren yang diformulasikan bersama dengan akar alang-alang, daun keji beling, daun meniran dan air dapat bermanfaat untuk mengatasi batu ginjal. Sedangkan nira aren yang diolah menjadi cuka berperan sebagai antimikroba (bahan pengawet) pada ikan dan menambah cita rasa pada makanan lainnya (Balittro 2008). Makalah ini akan membahas tentang pemanfaatan bagian pelepah aren yang tidak terlalu tua serta tidak terlalu muda untuk dimanfaatkan sebagai bahan baku kosmetika yang kaya antioksidan dan aman digunakan dalam jangka panjang.Kandungan Antioksidan pada Pelepah Aren

Antioksidan diperlukan tubuh untuk menangkal radikal bebas yang berdampak negatif terhadap kesehatan karena dapat merusak jaringan tubuh, sel, DNA dan enzimenzim tertentu (Supiyanti 2010). Antioksidan mampu meredam radikal bebas dengan mendonorkan atom hidrogennya sehingga dapat merubah radikal bebas menjadi non radikal. Peningkatan jumlah radiakal bebas dipicu oleh gaya hidup yang tidak sehat, seperti kebiasaan mengkonsumsi makanan instan, minuman beralkohol, merokok, terpapar bahan kimia berbahasa dan radiasi sinar matahari.

Tubuh mampu memproduksi antioksidan alami untuk menghambat kerusakan yang diakibatkan oleh kelebihan radikal bebas, namun dalam kondisi tertentu antioksidan alami dalam tubuh berkurang sehingga perlu asupan antioksidan dari luar. Penggunaan antioksidan tambahan yang dihasilkan dari hasil ekstraksi tanaman yang mengandung flavonoid dan fenolik mempunyai efek samping yang relatif lebih kecil dibandingkan dengan penggunaan antioksidan buatan (kimia).

Aren merupakan salah satu kekayaan hayati Indonesia yang mempunyai nilai guna tinggi. Pelepah aren memiliki kandungan antioksidan dan dapat ditemukan dengan mudah. Tepung pelepah aren dimanfaatkan secara tradisional untuk menghilangkan bekas luka pada kulit, menghilangkan rasa gatal dan abu pelepahnya digunakan sebagai kosmetik (Sangi et al. 2012). Informasi yang dibagikan oleh Sangi et al. (2012) bahwa tepung pelepah aren mengandung senyawa metabolit sekunder yaitu tanin yang merupakan golongan senyawa polifenol dan dapat berperan sebagai antioksidan alami.

Pelepah aren yang diekstrak dengan menggunakan etanol $70 \%$ maupun $96 \%$ berpotensi sebagai antioksidan alami. Hasil penelitian Fitriani (2014) menunjukkan adanya senyawa metabolit sekunder dalam ekstrak pelepah aren seperti saponin, steroit, triterpenonoid, tanin dan fenol. Menurut Maisuthisakul et al. 2007 senyawa fenolik memiliki gugus hidroksil yang mampu menghambat reaktivitas dari radikal bebas, sehingga semakin tinggi kadar fenolik maka semakin kecil nilai IC50 atau aktivitas antioksidannya semakin besar.

\section{Pelepah Aren sebagai Pencerah Kulit}

Proses perubahan warna kulit dari cerah menjadi kusam dikenal dengan istilah pigmentasi. Faktor pemicu pembentukan pigmentasi kulit wajah diantaranya paparan sinar ultraviolet, iritasi, genetika, usia, hormon, dan inflamasi. Produk pemutih kulit mengandung bahan aktif yang dapat menekan serta menghambat melamin yang sudah terbentuk sehingga akan memberikan warna kulit yang lebih cerah. Sebagian besar pencerah kulit wajah bekerja dengan menghambat pembentukan melamin melalui jalur inhibisi pada enzim tironase dan bahkan ada yang bersifak toksik terhadap melamin.

Tirosinase merupakan enzim bifungsional pada reaksi pembentukan melamin serta pigmen warna lainnya yang diperoleh dari oksidasi tirosin (Sambasiva et al. 2013). Tirosinase berperan sebagai pengoksidasi yang kuat bagi beberapa tipe fenolik seperti klorofenol, metilfenol, difenol, dan naftol. Namun, tirosenase pada proses reaksi enzimatik pencoklatan dalam buah yang rusak berperan 
sebagai katalisator (Chang 2009). Enzim ini berperan dalam pembentukan pigmen warna pada mamalia akan tetapi pembentukan pigmen warna yang berlebihan dapat memicu terjadinya melasma, bintik-bintik hitam atau tahi lalat, serta berbagai penyakit degeneratif lainnya. Tirosenase memiliki peran dari neurotoksik dopamin dan neurodegradasi dapat berasosiasi dengan penyakit parkinson (Zheng et al. 2008).

Hasil kajian yang dilakukan oleh Batubara et al. (2009) menyatakan bahwa beberapa jenis tanaman di Indonesia mempunyai kemampuan sebagai inhibitor tirosinase. Tanaman tersebut harus mempunyai kandungan senyawa-senyawa seperti kuersentin, stilbena, resveratrol, dan hidroksistilbena. Sedangkan kelompok logam mineral yang dapat menghambat laju aktivitas tirosenase dalam pembentukan melamin diantaranya $\mathrm{Zn}^{2+}, \mathrm{Mg}^{2+}$ dan $\mathrm{Mn}^{2+}$ (Thakam et al. 2012). Kelompok logam mineral yang telah umum digunakan dalam industri kosmetika antara lain silika, mika, alumina, zink dan magnesium (ISCC 2009).

Kearifan lokal yang tetap terjaga oleh masyarakat Tomohon memanfaatkan tepung pelepah aren sebagai bahan penghilang gatal-gatal di kulit dan penghilang luka bakar. Abu pelepah aren yang berwarna keputihan dikenal oleh masyarakat Jawa Barat sebagai sarerang kawung. Para wanita Sunda konon menggunakan sarerang kawung sebagai bedak (pupur) setiap hari agar kulitnya tampak halus dan bercahaya. Bedak sarerang kawung yang digunakan setiap menjelang tidur juga bermanfaat untuk memulihkan kulit penderita cacar air dan jerawat.

Ekstrak abu pelepah aren lebih berpotensi sebagai inhibitor tirosinase dibandingkan ekstrak simplisia pelepah aren. Bahan baku yang digunakan sebagai bahan pembuatan abu diperoleh dari pelepah aren yang telah terlepas dari pohonnya, berwarna hitam kecoklatan kemudian dibakar menggunakan tungku sehingga diperoleh abu berwarna putih. Bahan pelarut akuades mempunyai beberapa keunggulan dibandingkan etanol $96 \%$, diantaranya hasil rendemen lebih tinggi, daya inhibisi terhadap tirosinase lebih besar dan komponen-komponen yang terikat lebih komplek.

Ekstrak abu pelepah aren mampu menghambat aktivitas tirosenase terutama pada jalur difenolase dengan daya inhibisi lebih tinggi dibandingkan dengan ekstrak simplisia pelepah aren. Kandungan logam mineral yang terdapat dalam ekstrak abu pelepah aren seperti magnesium, zink, dan alumunium berperan dalam menghambat aktivitas tirosenase (Ervani 2013). Kandungan logam yang terdapat pada abu pelepah aren berpotensi sebagai inhibitor tirosinase dalam proses melanogenesis melalui bentuk kompleksnya seperti $\mathrm{Zn}^{2+}$ dan $\mathrm{Mg}^{2+}$ (Han 2006).

Kandungan alumunium dalam bentuk silika dan apabila berkaitan dengan silika dapat menghambat aktivitas dari tirosin fosfatase (Kapoor et al. 2010). Kompleks alumunium akan berkaitan dengan ligan atau mengganggu kestabilan dari enzim tersebut sehingga aktivitasnya menurun. Sedangkan alumunium dalam bentuk alumina dapat menghambat kinerja dari beberapa enzim salah satunya aktvitas dari NADP-isositrat dehidrogenase. Logam tembaga memilki aktivitas penghambatan aktivitas tirosenase dengan membuat aktivitas enzim tersebut melemah dan rusak karena pada dasarnya ion logam ini akan membentuk ikatan ligan dengan tirosenase sehingga menyebabkan kinerja dari tirosenase melemah. Ekstrak abu pelepah aren memiliki nilai IC50 sebesar $1458.92 \mu \mathrm{g} / \mathrm{ml}$.

\section{Pelepah Aren sebagai Anti Jerawat}

Jerawat adalah penyakit kulit yang terjadi karena adanya peradangan menahun polisebasea yang ditandai dengan adanya komedo, papul, pustul, nodus pada tempat predileksinya seperti pada muka, bahu, dada bagian atas, lengan atas dan punggung bagian atas. Jerawat dipicu adanya bakteri Propionibacterium acnes dan Staphylococcus aureus yang menghasilkan lipase pemecah asam lemak bebas dari lipid kulit, sehingga menimbulkan peradangan pada jaringan kulit. Selain itu, timbulnya jerawat juga dapat dipicu oleh sintesisdan sekresi hormon androgen 
pada remaja putra dan putri yang sedang dalam masa pubertas, ibu hamil, pengaruh penggunaan obat kontrasepsi, stress, iritasi dan hereditas (Chetana et al. 2012).

Upaya menanggulangi jerawat dapat dilakukan dengan pemanfaatan bahan-bahan alami yang mengandung antimikroba atau antibakteri. Beberapa tanaman yang telah umum digunakan sebagai anti jerawat diantaranya ekstrak daun teh, lidah buaya, serta beberapa jenis rimpang. Masyarakat Sumedang dan Sukabumi memanfaatkan pelepah pohon aren sebagai kayu bakar saat memasak nira aren menjadi gula dan sisa abu pembakaran digunakan sebagai bahan pemudar bekas luka, pembersih kulit wajah serta penghilang jerawat.

Pelepah yang digunakan adalah pelepah yang tidak terlalu muda dan tidak terlalu tua, yaitu pelepah ke-3 hingga pelepah ke-6. Hasil penelitian Andam et al. (2015) melaporkan bahwa pelepah aren memiliki kandungan metabolit sekunder berupa flavonoid, polifenol, tanin, saponin, kuinon, alkaloid, monoterpen dan seskuiterpen. Senyawasenyawa tersebut berpotensi sebagai anti bakteri. Mekanisme penghambatan pertumbuhan bakteri oleh golongan senyawa metabolit memiliki aktivitas yang berbeda.

Golongan senyawa flavonoid dapat mendenaturasi protein akibatnya dinding sel bakteri rusak dan gugus hidroksil tersebut masuk ke dalam inti sel bakteri, sehingga menyebabkan bakteri tersebut mati. Senyawa alkaloid yang tersedia pada pelepah aren dapat mengganggu komponen penyusun peptidoglikan pada sel abkteri, menyebabkan sel bakteri menjadi lisis. Terpenoid menyebabkan terjadinya lisis pada sel bakteri dengan mengikat protein, lipid dan karbohidrat yang terdapat pada mikroba. Polifenol dan tanin berperan dalam menghambat aktivitas enzim protease, menghambat enzim pada protein transpor selubung sel bakteri, dan destruksi atau inaktivasi fungsi materi genetik. Tanin juga berperan dalam merusak metabolisme bakteri dengan mekanisme mengkerutkan dinding sel bakteri yang mengakibatkan pada terganggunga permeabilitas sel.

\section{PENUTUP}

Pemanfaatan abu pelepah aren telah dilakukan oleh masyarakat di Jawa Barat dan Minahasa secara sederhana dan turun temurun. Abu pelepah aren yang berwarna keputihan dipercaya berkhasiat untuk menghaluskan kulit, menjadikan kulit tampak bercahaya, memudarkan bekas cacar air dan menghilangkan jerawat. Secara ilmiah telah dibuktikan bahwa ekstrak abu pelepah aren mempunyai kandungan logam mineral seperti magnesium, zink, dan alumunium yang berperan dalam menghambat aktivitas tirosenase sehingga menjadikan kulit tampak lebih cerah. Selain itu, pelepah aren memiliki kandungan metabolit sekunder berupa flavonoid, polifenol, tanin, saponin, kuinon, alkaloid, monoterpen dan seskuiterpen yang berpotensi sebagai anti bakteri penyebab timbulnya jerawat. Senyawa tanin yang merupakan golongan senyawa polifenol dan dapat berperan sebagai antioksidan alami. Dengan demikian, pemanfaatan abu pelepah aren sebagai bahan kosmetika pencerah kulit dan anti jerawat yang kaya antioksidan alami dapat dilakukan dalam skala industri modern untuk mengangkat potensi lokal masyarakat Indonesia serta meningkatkan kesejahteraan petani aren.

\section{DAFTAR PUSTAKA}

Andam M.D., Ratnawati J., Sukmanengsih F. 2015 Aktivitas antimikroba ekstrak etanol dan fraksi pelepah Aren terhadap Propionibacterium acnes dan Staphylococcus aureus. Kartika-Jurnal IImiah Farmasi. 3(2):22-26.

Anonim. 2014. Bedak Aren penghilang noda di wajah dari sarerang kawung. http://bedak-

aren.blogspot.co.id/2015/08/bedakaren-penghilang-noda-di-wajah.html (diakses tanggal 1 Juni 2016).

Balai Penelitian Tanaman Palma [Balit Palma]. 2014. Usulan Pelepasan Varietas Akel Toumuung Hasil Kerjasama Balai Penelitian Tanaman 
Palma dan Pemerintah Kota Tomohon. http://balitka.litbang.pertanian.go.id/?s= aakel+toumuung\&lang=en (diakses tanggal 1 Juni 2016).

Balai Penelitian Tanaman Rempah, Obat dan Aromatik [Balittro]. 2008. Penggunaan tanaman kelapa, pinang dan aren sebagai tanaman obat. http://balittro.litbang.deptan.go.id. (diakses tanggal 1 Juni 2016).

Batubara I., Darusman L.K., Mitsunaga T., Rahminiwati M., Djauhari E. 2010. Potency of Indonesia medicinal plants as tyrosinase inhibitor and antioxidant agent. J.Biol.Sci 10:138-144.

Chang T.S. 2009. An updated review of tyrosinase inhibitors. Int. J. Mol. Sci, 10:2440-2475.

Chentana P., Karadi RV., Lokesh BK., Amit SK. 2012. Screening of selected herbal plants for anti jerawat properties. International Journal of Drug Development \& Research. Vol 4-2:216222.

Ervani M.S.L. 2013. Potensi abu dan simplisia pelepah Aren (Arenga pinnata) sebagai inhibitor tirosenase [Skripsi]. Departemen Biokimia. Fak. Matematika dan IImu Pengetahuan Alam, IPB. Bogor.

Fitriani N.M. 2014. Aktivitas antioksidan ekstrak pelepah pohon Aren (Arenga pinnata Merr.) [Skripsi]. Departemen Biokimia. Fak. Matematika dan IImu Pengetahuan Alam, IPB. Bogor.

Han H.Y, Zou H.C., Jeon J.Y., Wang Y.J., Xu W.A., Yang J.M., Park Y.D. 2006. The inhibition kinetics and thermodinamic changes of tyrosinase via the zinc ion. Biochimica et Biophysica Acta 1774(2007):822-827.

[ISCC] Indian Cosmetic Chemistry. 2009. News update: mineral make-up. Vol 01. New Delhi:ISCC.

Iswanto A.H. 2009. Aren (Arenga pinnata). [Karya Tulis]. Medan (ID): Universitas Sumatera Utara.

Kapoor S., Girish T.S, Mandal S.S, Gopal B., Bhattacharyya A.S. 2010. Inhibition of a protein tyrosinase phosphatase using mesoporous oxides. J. Phys Chem B. 114(9):311.17-21.

Maisuthisakul P., Suttajit M., Pongsawatmanit R. 2007. Assessment of phenolic content and free radical-scavenging capacity of some Thai indigenous plants. Food Chemistry. 100:14091418.

Sambasiva R.K.R.S., Tripathy N.K., Srinivasa R.D., Prakasham R.S. 2013. Production, characterization, catalytic and inhibitory avtivation of tyrosinase. Res. J. Biotech. 8(1):83-95.

Sangi M.S., Momuat L.I., Kumaunang M. 2012. Uji toksisitas dan skrining fitokimia tepung gabah pelepah Aren (Arenga pinnata). Jurnal IImiah Sains. 12(2):127-134.

Supiyanti W., Wulansari E.D., Kusmita L. 2010. Test of antioxidant activity and determination of total anthoccyanin content in rind of mangosteen (Garcinia Mangostana L). Obat Tradisional 15(2):64-70.

Thakam A., Saewanm N., Kittigowittang K., Jimtaisong A. 2012. Antioxidant and antityrosinase activities of metal complexes of Curcuma petiolata extract for cosmetics applications. $1^{\text {st }}$ mae Fah Luang University International Conference 2012:1-10.

Wiwin M. 2011. Studi etnobotani tumbuhan yang dimanfaatkan sebagai bahan perawatan pra dan pasca persalinan oleh masyarakat Samin Kecamatan Margomulyo Kabupaten Bojonegoro [Skripsi]. Fakultas Sains dan Teknologi:UIN Maulana Malik Ibrahim Malang. 